\title{
UKRAJNA KÖZÖSSÉGI FINANSZÍROZÁSÚ, KATONAI CÉLOKAT SZOLGÁLÓ OKTOKOPTEREINEK ELEMZÉSE
}

\author{
ANALYSIS OF UKRAIN'S CROWDFUNDED, MILITARY PURPOSE \\ OCTOCOPTERS
}

\author{
HUSZÁR Péter \\ (ORCID: 0000-0001-6169-3777) \\ huszar.peter.92@gmail.com
}

\begin{abstract}
Absztrakt
A kelet-ukrajnai háború hatására Ukrajnában több csoport is alakult, amelyek dedikált célja, a honvédelem segítése. A cikkben a szerző részletesen elemzi és bemutatja az egyik ilyen ukrán irreguláris katonai csoport, az Aerorozvidka által épitett és használt drónokat. Az elemző tevékenység alapjául az interneten fellelhető számos média megjelenésük, a tagokkal készült interjúk és beszámolók szolgáltak. A publikáció célja az olvasó számára pontosan bemutatni, azokat a civil és ipari pilóta nélküli repülő eszköz alkalmazásokban elterjedt, kereskedelmi forgalomban bárki által szabadon hozzáférhető részegységeket és alkatrészeket, amelyeket ez az önszerveződő csoport rendszeresen használ légi felderitésre és információ gyüjtésre. Ezzel támogatja Ukrajna honvédségét, azon belül kifejezetten a tüzérséget és a döntéshozási folyamatokat.
\end{abstract}

Kulcsszavak: UAV, Aerorozvidka, közösségi finanszírozású háború, hadi startup

\begin{abstract}
Due to the Eastern Ukrainian war several groups has been established in Ukraine. Their definitive goal to help the Ukrainian military. In this article the author analyzes in details and demonstrates the drones built and used by one of these irregular military groups, namely the Aerorozvidka. The analysis based on their appearances in the news, social media, and interviews with the members. The aim of this publication is to promptly specify those widespread off-the-shelf parts which are widely used in civilian and industrial UAV applications and this self-organized group is using also for air reconnaissance and information gathering on a regular basis in order to support the Ukrainian army, their artillery and the decision making processes.
\end{abstract}

Keywords: UAV, Aerorozvidka, crowdfunded war, war startup 


\section{BEVEZETÉS}

Az elmúlt évtizedek fegyveres konfliktusaiban a gépek, gépesített eszközök mind nagyobb és nagyobb teret kapnak, legyen szó akár felderítésröl, akár pusztításról. Nincs ez másként a pilóta nélküli repülő eszközök, az elterjedten használt angol kifejezés szerint: Unmanned Aerial Vehicle, rövidítve: UAV (továbbiakban drónok) esetében sem. Az élőerő megóvásának szándéka, a nehezebb felderíthetőség, valamint az egyre komplexebb feladatok ellátását lehetővé tevő drónok nélkül napjaink fegyveres konfliktusai aligha lennének elképzelhetőek. Korunkat fémjelző technológiai és számítástechnikai fejlődés nem csak a civil mindennapokat befolyásolja erőteljesen, hanem a hadviselésre is jelentős hatással van. A számítógépek, mobiltelefonok és a kibertér mindennapi életünk részévé válása gyökeresen változtatja meg a korábbi hadviselési paradigmákat. A félvezető eszközök növekvő teljesítménye, csökkenő ára és egyre egyszerübb programozhatóságának eredményeként, egyes civil felhasználásra szánt müszaki és számítástechnikai eszközök hatékonyan használhatóak katonai célok elérésére. A korszerü, naprakész technológiai megoldásokat használó haditechnikai eszközök fejlesztése, gyártása, rendszeresítése és rendszerben tartása azonban igen költséges és nem minden nemzet hadereje tud azzal lépést tartani. Mit tehet egy olyan ország, amely hadereje hasonló sorsra jutott, de mégis rákényszerül új, esetleg alternatív források bevonására és azok leghatékonyabb felhasználására, hogy legalább minimális szinten biztosítsa haderejének ellátását?

\section{AZ AEROROZVIDKA BEMUTATÁSA}

A kelet-ukrajnai háború 2014-es kirobbanását követően az ukrán légierő óriási veszteségeket szenvedett. Legalább hét darab gyengén felszerelt, önvédelemre képtelen MiG vadászrepülő és több harci helikopter, könnyü célpontként semmisült meg az összecsapások során pár nap leforgása alatt. A bombázások hatására több repülőtér is a földdel vált egyenlővé. Az ország hadserege ekkorra már évek óta minimális finanszírozással müködött, a meglévő haditechnikai eszközök, fegyverek nagy része külföldön került értékesítésre, sokszor feltételezhetően illegális körülmények között [1]. Mindezek következtében a hadsereg nehézségekbe ütközött alapvető honvédelmi feladatinak ellátása során. Megfelelö információk hiányában pedig a döntéshozás minősége és a döntési ciklusok ideje tovább hátráltatta ezeket a folyamatok. Ukrajna ezek után kérésének megfelelően ígéretet kapott az Egyesült Államoktól, hogy nem fegyverekkel, hanem inkább radarokkal, páncélozott jármüvekkel és felderítő drónokkal támogatja majd Ukrajnát. [2] [3] [4] Ez a folyamat azonban csak nagyon lassan és nehézkesen valósult meg. [5] Viszont pilóta nélküli repülőkre Ukrajna honvédségének továbbra is nagy szüksége volt, elsősorban légi felvételek és információ gyüjtés céljából.

E probléma megoldására több, mérnökökből, programozókból és katonákból alakult csoport is létrejött, amelyek dedikált célja volt, hogy könnyen és olcsón elérhető civil felhasználásra szánt drónokkal oldja meg a fennálló hiányt. Közülük az egyik legaktívabb az Aerorozvidka. Müködése során szoros kapcsolatban áll az ukrán katonasággal. Mára számos UAV-t, földi állomást és az azokhoz tartozó egyéb eszközöket sikerült ilyen módon kifejleszteniük, beszerezniük vagy átalakítaniuk [6]. 
Ezek a szervezetek állami források hiányában közösségi finanszírozási alapon fejlesztenek és tartják fenn magukat. A crowdfunding, azaz közösségi finanszírozás egy olyan alternatív finanszírozási forma, melyben a forrásokat bevonni kívánó vállalkozás és a potenciális befektető között nem egy bank, hanem egy internetes portál teremti meg a kapcsolatot. [7] Ez manapság sokak számára összefonódott az egyik legnagyobb közösségi finanszírozásra szakosodott portállal, a Kickstarter-rel és az ehhez hasonló online felületekkel, ahol bárki, akinek van egy jó ötlete és tőkét szeretne bevonni annak megvalósításához, akkor azt összegyüjtheti ezeken a platformokon keresztül. Feltéve, ha talál olyan befektetöket, adakozni vágyókat, akik számára szimpatikus a cél és adnak némi pénzt annak elérése érdekében.

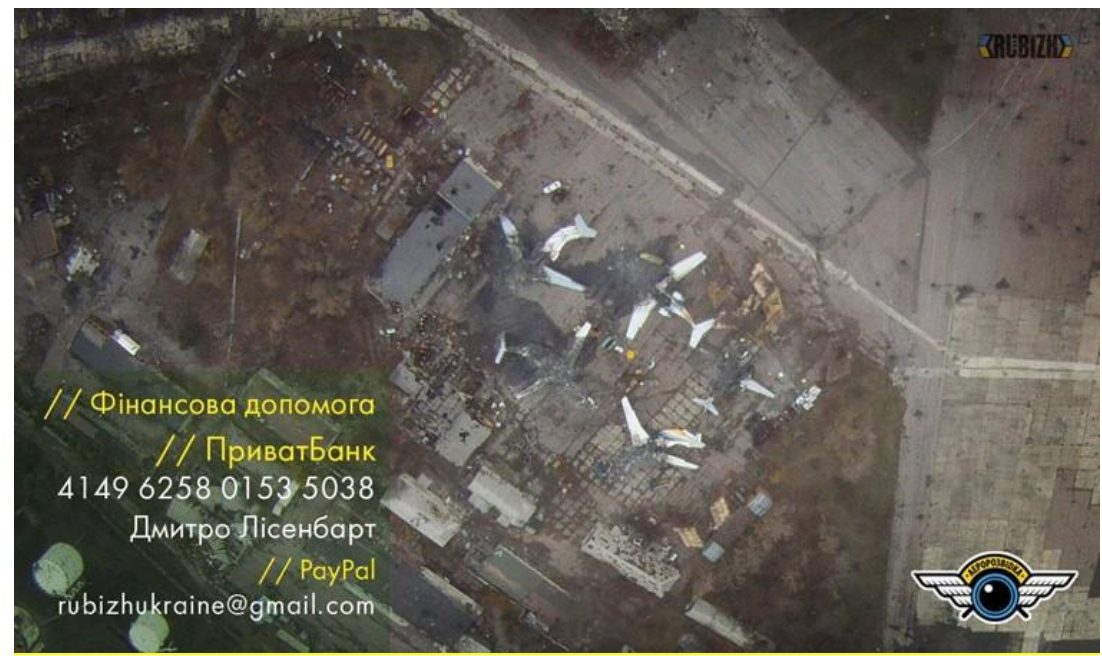

1. ábra A Donecki nemzetközi repülőtér maradványai az Aerorozvidka felvételén Hiba! A hivatkozási forrás nem található.

Működésük hasonlít egy startup-hoz¹. Megtalálhatóak az interneten, saját honlapjuk van, ahol az egyes kijelölt pénzügyi célok státuszát nyomon lehet követni, a projektek leírását meg lehet tekinteni. Jelen vannak több közösségi médiumon, Facebook-on, Twitter-en és YouTubeon is, ahol időről-időre beszámolnak tevékenységükről. Az adományokat egy internetes pénzügyi szolgáltatásokat nyújtó felületen, a PayPal-on keresztül fogadják. Sőt azok, akik arccal és névvel vállalják a médiaszereplést, a világ legnagyobb szakmai közösségi oldalán, a LinkedIn-en is megtalálhatóak. Az Aerorozvidka alapítói Natan Chazin, aki az ukrán fegyveres erök tanácsadója, Igor Korolenko, közremüködött a PD-1 UAV kifejlesztésében a People's Project keretein belül és Volodymyr-Kochetkov Sukach.

Média megjelenéseik során számos videót és képet közölnek azokról a részben saját fejlesztésü, részben pedig megvásárolt, majd átalakított eszközökröl, amelyeket használnak. Mindezek alapján valóban, szinte kivétel nélkül, civilek számára elérhető, legálisan beszerezhető alkatrészekből épülnek. A legtöbb alkatrész internetes web áruházakból megrendelhetö, melyet beépítenek drónjaikba. A cikkben ezeket a közösségi finanszírozásból létrejött, alapvetően civil célokra szánt alkatrészekből elkészített, ám katonai felhasználásra épült mikro és mini multirotoros drónokat vizsgálom és részletesen bemutatom azok felépítését és müszaki jellemzöit. Különös tekintettel a csoport által leggyakrabban használt oktokopterekre. Az elemzés alapjául az Aerorozvidkáról megjelent cikkek és riportok, valamint az általuk a közösségi médiában közzé tett képek illetve videók szolgálnak.

\footnotetext{
${ }^{1}$ Startup: Nagy növekedési potenciállal rendelkező induló vállalkozás. [9]
} 


\section{Repülésszabályozó egység}

Az említett oktokopterekben a források alapján a felhasznált repülés szabályzó és robotpilóta egységek a két legismertebb civil drónokat gyártó cég által fejlesztett eszközök valamelyike található meg. Az egyik a sokak számára ismerős kínai gyártó, a DJI NAZA M V2 terméke, a másik pedig az Amerikai 3D Robotics Pixhawk 2.4.8 A DJI NAZA vezérlői kevésbé módosíthatóak, átalakításokra kevesebb lehetőség van. Sem a szoftver sem pedig a hardware nem nyíltforrású, viszont nagyon felhasználóbarát és gyorsan elsajátítható a használatuk. Stabil, jól bevált eszközök, melyeket leggyakrabban légi fotózásra és videózásra használnak. Ezzel szemben a 3DR a Pixhawk repülés szabályzóit kifejezetten az egyedi készítésủ drónokba szánja, olyan felhasználókat megcélozva, akik saját igényeikre szabott eszközöket készítenek egyedi funkciókkal. Nyílt forráskódú, mind a szoftver mind pedig a hardver, így azokat bárki elkészítheti magának és a legmélyebb szintig módosíthatja azt céljainak megfelelően, azonban ez jóval több szakértelmet igényel. Jellemzően távérzékeléssel kapcsolatos feladatokra használják. Mindkét gyártótól elérhető ipari alkalmazásra szánt, többszörösen redundáns kivitelü, nagy megbízhatóságú vezérlő is az itt bemutatottakon kívül. Az említett két repülés szabályozó inkább hobbi célokra, mintsem professzionális alkalmazásokra készült, annak ellenére, hogy sokan használják őket ilyen céllal is.

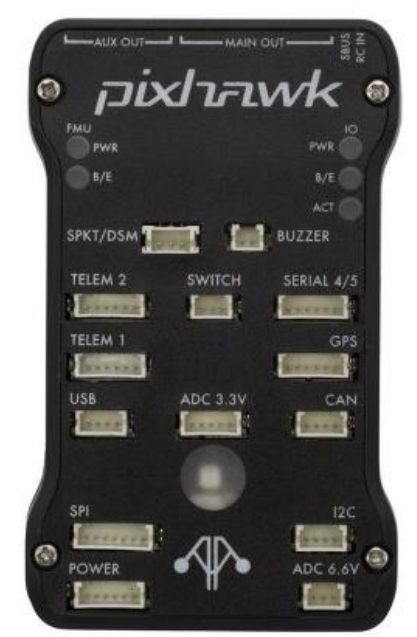

2. ábra 3DR Pixhawk 2.4.8 Hiba! A hivatkozási forrás nem található.

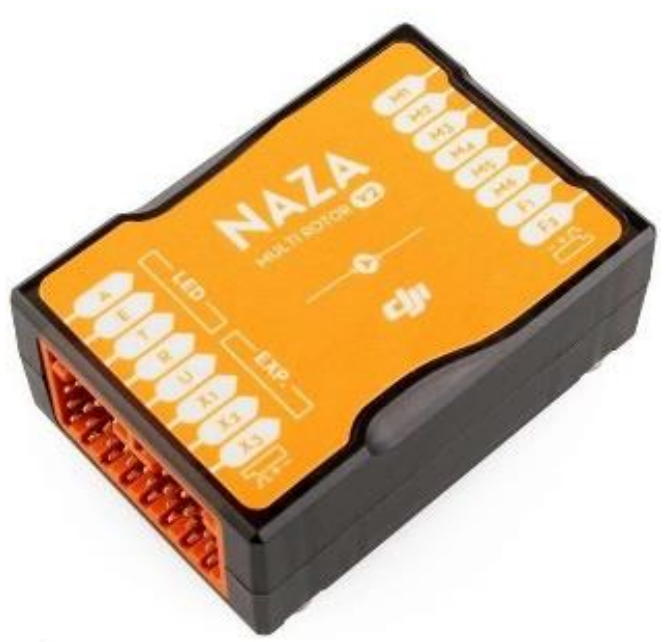

3. ábra DJI NAZA MV2 [12]

\section{Propulziós rendszer}

A csoport egyik tagjával készült interjú szerint 40 perc repülési időt várnak el a koptereiktől, hogy azok az oda és vissza utakon kívül minimum 20 percet 400-500m magasságban tudjanak tölteni és ott ellátni a feladataikat. [12] Ehhez legalább 15-20Ah kapacitású akkumulátorokra van szükségük. Ezek súlya $2.1 \mathrm{~kg}$-ra becsülhető ${ }^{2}$. A megvizsgált képek és videók alapján elmondható, hogy a csoport a saját építésủ oktokopterein 18650 típusú Li-ion cellákból készítette saját akkumulátorokat használ. Ez meglepő, hiszen a multirotoros drónok tápellátására manapság tradicionálisan Li-po akkumulátorokat használnak. Ez az FPV

${ }^{2}$ Az ilyen célú felhasználásra megfelelő SONY VTC3 típusú cella 45.1g. A 4. ábra alapján 45 cella kerül felhasználásra. Ezekből kiszámolható, hogy 2029.5g csak a cellák tömege. Ezt tovább növelik a kábelek, csatlakozók és ragasztó anyagok.

${ }^{3}$ FPV: First Person View - Élő kamerakép alapján történő drón irányítás 
versenyzésre használt quadkopterek elterjedésével egyre csak erősödő tendenciát mutat azok müszaki jellemzői miatt. Azonban a nagyméretü oktokopterek esetében az alacsony KV hányadossal ${ }^{4}$ rendelkező motorok magasabb tápfeszültség mellett tudják csak leadni a szükséges fordulatszámot és teljesítményt. Jellemzően 4-6 akkumulátor cella soros kapcsolásával érhető el a szükséges $\sim 16-25 \mathrm{~V}$-os tápfeszültség. Ezenkívül velük nagyon finom, meggondolt manővereket enged végrehajtani a robotpilóta. A reakció és beállási idők sokkal lassabbak, mint a nanoquadoké, amelyeknek a lehető legfürgébbnek és reszponzívabbnak kell lenniük. Továbbá a terhelés a nyolc nagyteljesítményü motoron és azok vezérlőin sokkal arányosabban szétoszlik, mint négyen, így azok áramfelvétele viszonylag egyenletes. Ezek eredményeképpen adódhatott számukra a Li-ion cellák nyújtotta lehetőség. A legtöbb laptop és más hordozható elektronikai eszközeink is ezt használják. Multirotoros alkalmazások szempontjából alapvetően két hátrányuk van. Az impulzusüzemü áramleadási képességük és teljesítménysürüségük alacsonyabb, mint a Li-po akkumulátoroké. Előnyük, hogy olcsóbbak és könnyebben beszerezhetők a tömeggyártásnak köszönhetően.

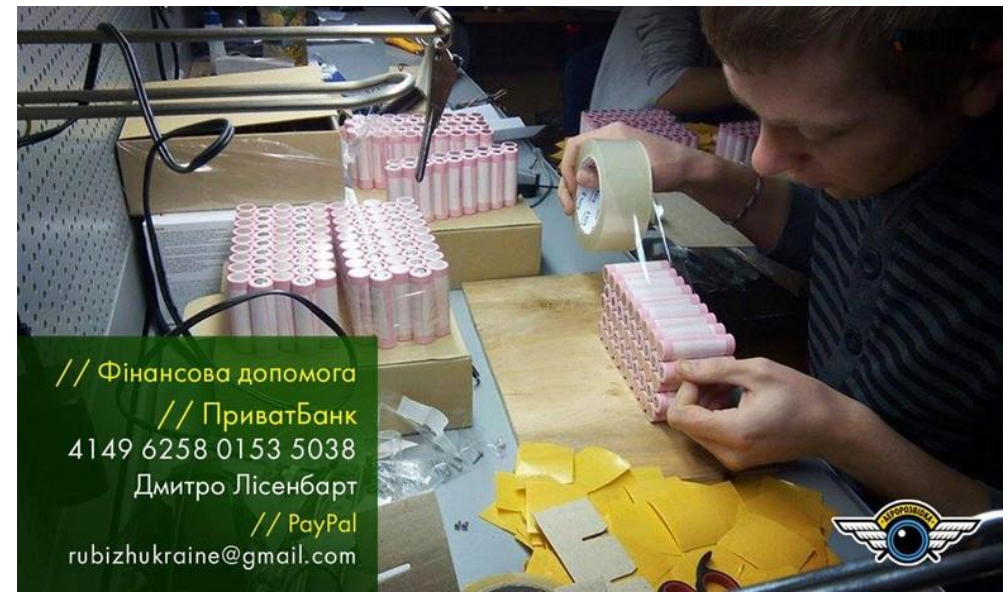

4. ábra 18650-es Li-Ion cellákból épülő akkumulátor Hiba! A hivatkozási forrás nem található.

A BLDC ${ }^{5}$ motorok, melyeket felhasználnak kifejezetten a nagy multirotoros drónokhoz készült változatok. Alacsony KV állandó, lapos profil és $50 \mathrm{~mm}$ feletti forgórész átmérö jellemzi. Ezeket a motorokat 15-19”-es „T” vagy „folding” kialakítású karbonszálas propellerekkel szerelik. A motorokhoz adatlapi ajánlások alapján $60-80 \mathrm{~A}$ fázisáramra és $25 \mathrm{~V}$ os tápfeszültségre tervezett $\mathrm{ESC}^{6}$-t kell használni.

\section{Vezeték nélküli kommunikációs csatornák}

Földi állomásaik alapvetően egy laptopból, a telepített, adott repülés szabályozó egységhez használható szoftverekböl, egy monitorból, melyen az élő kamerakép látható és egy távirányítóból állnak. A drónok irányítására szinte kizárólag egy adott típusú távirányítót használnak, az FrSky Taranis X9D Plus-t. Ez egy immáron több éve a piacon elérhető, folyamatosan fejlesztett, nyílt forráskódú távirányító. Igen népszerü és megbízható darabként tartja számon nemcsak a hobbi, de a professzionális drón használó közösség is világszerte. Népszerüsége miatt, sok más gyártó is készít hozzájuk kiegészítőket, így a legapróbb részletekig módosítható, testreszabható mind a szoftvere, mind pedig a hardvere. Szemmel

\footnotetext{
${ }^{4}$ KV hányados: BLDC motor fordulatszámát meghatározó állandó

${ }^{5}$ BLDC motor: Brushless Direct Current Electric Motor - Kefe nélküli egyenáramú motor

${ }^{6}$ ESC: Electronic Speed Controller - Elektromos sebesség szabályzó
} 
látható módosítás például az eredeti $2.4 \mathrm{GHz}$-es adó-vevő modulok lecserélése. A távirányítókon rendre két antenna fedezhető fel. Az egyik a gyári teljes hullámú $2.4 \mathrm{GHz}-\mathrm{es}$ dipól, ami 3dBi nyereségü, és egy másik annál jóval hosszabb dipól. Ebből arra lehet következtetni, hogy egy alacsonyabb frekvenciájú adó-vevő modult használnak. Ezekhez a távirányítókhoz beszerezhető 900 és $433 \mathrm{MHz}$-es adó-vevők is, melyek teljesítménye nagyobb az eredeti $2.4 \mathrm{GHz}$-en müködő adó-vevőknél és ezek a frekvencia tartományok sokkal kedvezőbbek a nagytávolságú, FPV vagy $\mathrm{BLOS}^{7}$ repülésekhez is. A payload, azaz hasznos teher, szinte mindig valamilyen kamera. Gyakran használnak GoPro sport kamerákat, de eddigi müködésük során hőkamerával ellátott drónokat és többtengelyes kamera stabilizátorokat is fejlesztettek. A különféle képalkotó eszközökön kívül meteorológiai szenzorokat, mint például szélirány és szélsebesség mérő müszereket lehet megfigyelni. Valamint felfedezhető, hogy próbálkoznak különböző robbanó szerkezetek célra ejtésével is. A hasznos teher kommunikációs csatornája $5.8 \mathrm{GHz}$-es, illetve $1.2 \mathrm{GHz}$ frekvencia sávban müködik. Ezen keresztül továbbítják az élő kameraképet a földi szegmensnek, ahol azt különböző nagynyereségü, irányított antennákkal veszik. Az adó oldalon jól megfigyelhetőek a 2-3 dB nyereségü körpolarizált „cloverleaf” antennák. Sugárzási karakterisztikájuk nagyon hasonlít a dipól antennáéhoz, viszont a körpolarizáltság zavarvédettebbé teszi a lesugárzott videó jelet.

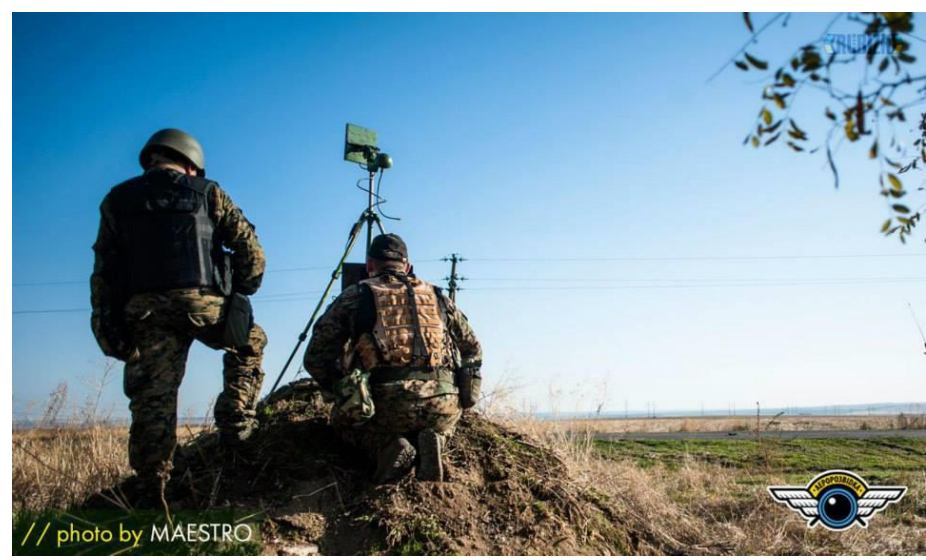

5. ábra Nagy nyereségü, irányított mikrohullámú patch antenna a földi szegmens oldalán Hiba! A hivatkozási forrás nem található.

\section{Az oktokopter vázszerkezete és felépítése}

Az oktokoptereik szerkezeti kialakítása követi a tradicionális felépítést. A motorok $45^{\circ}$-ra helyezkednek el. A légcsavarok egy továbbfejlesztett változatot leszámítva, nem dihedrális állásúak. Annak ellenére, hogy az ilyen nagyméretü multirotoros kamera drónok esetében bevett gyakorlat a stabilitás növelése érdekében a dihedrálás. A váz szénszálas és üvegszálas kompozit anyagok, valamint alumínium elemek felhasználásával épült. A nyolc rotor pedig nem csak a nagyobb hasznos teher szállítását teszi lehetővé, hanem növeli a megbízhatóságot is. Egy multikopter esetén a több mint négy rotor használata redundanciát biztosít olyan meghibásodásokkal szemben, amelyek egyetlen motor és az általa létrehozott felhajtóerő elvesztését eredményezik. Ilyen esetekben ezek az drónok nem zuhannak le, hanem biztonságosan földet tudnak érni vagy folytatni tudják útjukat. Megállapítható továbbá, a használt GNSS ${ }^{8}$ és iránytü modulok rögzítésének pozíciója alapján, hogy az oktokoptereket „I” konfigurációban használják „V” helyett. E két konfiguráció között az a különbség, hogy a

${ }^{7}$ BLOS: Beyond Line of Sight - Látóhatáron túli

${ }^{8}$ GNSS: Global Navigation Satellite System - Globális navigációs műhold rendszer. 
kopter számára kijelölt virtuális elöre irány egybe esik-e egy, a középpontján és egy kijelölt motoron átmenő egyenessel („I” konfiguráció), vagy az a középpontja és két kijelölt motor közti szakasz felező pontján átmenő egyenessel esik egybe (,V” konfiguráció). Az „I” konfiguráció hátránya, hogy kevésbé stabil és kisebb nyomatékot lehet vele kifejteni bólintó mozgás során a „V”-hez képest.

\section{ÖSSZEFOGLALÁS ÉS KÖVETKEZTETÉSEK}

Véleményem szerint az Aerorozvidka és a hozzájuk hasonló csoportok tevékenysége több olyan dologra is felhívja a figyelmet, mely a civil és a katonai drónok felhasználását, fejlesztését és elérhetőségét markánsan befolyásolni fogja a jövőben. A kutatás eredményeit az 1. táblázatban foglaltam össze. Látható, hogy szinte minden részegység pontosan meghatározható, amelyek nem, a többi részlet és az azok által támasztott követelmények alapján jól behatárolhatóvá válnak. A tény, hogy a példaként felsorolt eszközök mindegyike kereskedelmi forgalomban szabadon hozzáférhető, legalább akkora előny, mint amekkora hátrány. Az egyértelmü hátrány, hogy ezek az eszközök nem megfelelö kezekbe kerülve, akár terrorista célokat is szolgálhatnak. Jelen közleményben igyekeztem azt is bemutatni, hogy az ilyen alkatrészekből épült drónokat könnyen meg lehet ismerni, azokat vissza lehet fejteni, viszont a gyártóval is együtt lehet müködni adott felhasználási módok kivédése érdekében. A védekezés ilyen tekintetben egyszerübben megoldható, mint az eleve titkos körülmények között tervezett drónok esetében.

\begin{tabular}{|c|c|c|}
\hline Részegység & \multicolumn{2}{|c|}{ Aerorozvidka által használt típusok és jellemzőik } \\
\hline FCU & DJI NAZA MV2 & 3DR Pixhawk 2.4.8 \\
\hline GPS & $\begin{array}{l}\text { DJI NAZA MV2 GPS/Compass module } \\
\text { (Ublox Neo 6) }\end{array}$ & Ublox Neo M8N \\
\hline \multirow{4}{*}{ BLDC motor } & \multicolumn{2}{|c|}{ KV hányados: $170,230,300$} \\
\hline & \multicolumn{2}{|c|}{$\mathrm{d}_{\text {rotor }}[\mathrm{mm}]: 50,52,60,70$} \\
\hline & \multicolumn{2}{|c|}{$1_{\text {rotor }}[\mathrm{mm}]: 5,6,16$} \\
\hline & \multicolumn{2}{|c|}{ pl.: Quanum MT 5206, GARTT ML 6016, T-MOTOR U8 } \\
\hline Propeller & \multicolumn{2}{|c|}{ 1755, 1855 típusú pl.: Quanum carbon-fiber T-type $18 x 55$} \\
\hline ESC & \multicolumn{2}{|c|}{$\begin{array}{l}\text { Pontos típus ismeretlen, de a többi alkatrész jellemzöiből következik, hogy 60-80A } \\
\text { fázisáramra és } 16-25 \mathrm{~V} \text { tápfeszültségre méretezettet használnak. pl.: T-motor Flame 80A } \\
\text { HV }\end{array}$} \\
\hline Akkumulátor & \multicolumn{2}{|c|}{ 5s9p kapcsolás, 18650 típusú Li-ion cellákból pl.: 45 db Sony VTC3 cellából épült. } \\
\hline $\mathrm{CNPC}^{9}$ & \multicolumn{2}{|c|}{$\begin{array}{l}\text { FR Sky Taranis X9D távirányító, R9M (900MHz) és Open LRS (433 MHz) adóvevő } \\
\text { modulokkal. }\end{array}$} \\
\hline $\mathrm{PC}^{10}$ & \multicolumn{2}{|c|}{$\begin{array}{l}\text { Adó pontos típusa ismeretlen. A jellegzetes körpolarizált „cloverleaf” antennák mérete } \\
\text { alapján viszont elmondható, hogy } 5.8 \mathrm{GHz} \text {, valamint } 1.3 \mathrm{GHz} \text {-es adókat használnak, pár } \\
\text { száz mW adóteljesítmény mellett. Ilyen például a Boscam TS832 típus }\end{array}$} \\
\hline Váz & \multicolumn{2}{|c|}{$\begin{array}{l}\text { Pontos típus ismeretlen maradt, minden bizonnyal saját készítésü. Tarot Iron Man 1000, } \\
\text { Tarot 960, Tarot X8 jellegü. }\end{array}$} \\
\hline
\end{tabular}

${ }^{9}$ CNPC: Control and Non-Payload Communication - A drón irányítására használt kommunikációs csatorna

${ }^{10}$ PC: Payload Communication - A drón által szállított hasznos teher kommunikációs csatornája 
1. táblázat Az Aerorozvidka oktokoptereiben katonai célokra leggyakrabban használt civil felhasználásra szánt, kereskedelmi forgalomban kapható alkatrészek föbb jellemzői és típusai. (Hiba! A hivatkozási forrás nem található.[13][12] szerkesztette a szerző)

Amennyiben a fegyveres konfliktus kontextusából kiemelve vizsgáljuk a kérdést, ezek az alkatrészek és a belőlük összeépített pilóta nélküli repülő rendszerek arra kiválóak, amire alapvetően azok gyártói szánták őket. Fotók és videók madártávlati elkészítésére. A civil és ipari felhasználás szempontjából azonban megállapítható, hogy egyre magasabb színvonalú drónokra lehet szert tenni, melyek megbízhatósága, üzemideje, autonómiájának szintje egyre csak nő. A velük elvégezhető feladatok komplexitása is hasonló tendenciát mutat. Szélesedik az elérhető alkatrészek és alegységek spektruma a nyílt forrású eszközök között is. Ennek azért van nagy jelentősége, mert csökken a gyártók által gyakorolható kontroll. A drónok általi csomagszállítás a logisztikát, a nagyfelbontású és multi spektrális légi fotók könnyebb hozzáférhetősége például a mezőgazdaságot fogja gyökeresen megváltoztatni. Az 5G széleskörü elterjedésével és az általa lehetővé tett gép-gép kommunikáció, alacsony késleltetésű, nagy megbízhatóságú mobil kommunikációs technológiák, valamint az erre épülő szolgáltatások ezt a folyamatot csak tovább fogják erősíteni. Ez a terület exponenciális fejlődését prognosztizálja az elkövetkező tíz-húsz évre.

Amennyiben katonai és védelmi szempontok szerint vizsgáljuk a civil felhasználásra szánt drónok hadi, esetleg terrorizmusra történő felhasználását, úgy jó kiindulási pont Igor Korolenko egyik nyilatkozata. Szerinte a drónokkal történő információ gyüjtés kapcsán széles körben elfogadott tény, hogy az veszélytelen. Az operátor sértetlenül végezheti tevékenységét, legrosszabb esetben is csak a pilóta nélküli repülö és esetleg a gyüjtött információ veszhet oda, az értékes humán erőforrás, akit csak hosszas kiképzés után tudnak pótolni, sértetlen marad. Ez a vélekedés viszont csak akkor lehet helytálló, ha a drón alatt olyan professzionális katonai eszközöket értünk, mint amilyen például a Global Hawk. A müholdas kommunikációnak és a több tíz órás repülési időnek köszönhetően valóban, a drónt és a kezelőjét egy fél világ választja el. A poszttraumatikus sokkot és a lelki sérüléseket leszámítva, fizikális sérülés nem éri. Azonban a relatív olcsó, nyíltforrású COTS ${ }^{11}$ alkatrészekből épült és civil felhasználásra szánt drónok esetében ez az elképzelés téves. Korolenko nyilatkozatában azt is elmondja, hogy az Aerorozvidka drón kezelői közül többen életüket vesztették, mert a használt eszközök könnyen felderíthetőek és bemérhető a kezelő pontos helyzete. Ezért a légi felderítő csoportoknak folyamatosan változtatniuk kell pozíciójukat és kellő elővigyázatossággal kell eljárniuk a müveletek során. [1] [6] Ezeket a drónokat és kezelöiket a szemben álló fél modern, orosz gyártmányú Krashuka-2 és Krashuka-4 elektronikai felderítő és zavaró jármüveikkel már több ízben felderítették és hamis koordinátákkal félrevezették azok GPS vevőit (GPS spoofing). [14] A drónok kizárólag müholdas helymeghatározási rendszerekre alapozott müködési problémáira Wührl Tibor is felhívja a figyelmet egyik tanulmányában [15]. A civil és ipari drónok sok szempontból elmaradnak katonai célokra tervezett társaiktól és ezek a különbségek csökkentik hadi alkalmazhatóságukat. Az ISM $^{12}$ frekvencia sávok használata az elektromágneses álcázatlanság és az elektromágneses spektrumban kibocsájtott jellegzetes mintázatok felderíthetővé és sebezhetővé teszik azokat.

A civil és katonai felhasználásra szánt drónok és az általuk használt technológiák között egyre nagyobb átfedés figyelhető meg. Azonban nincs ez másként a hibrid hadviselés más területein sem. A információs és számítógép hálózati müveletek során is egyre nehezebb

\footnotetext{
${ }^{11}$ COTS: Commercial off-the-shelf - Kereskedelmi forgalomba hozott késztermék.

12 ISM: Industrial Scientific and Medical frequency ranges - Ipari, tudományos és orvosi használatra fenntartott frekvencia sávok.
} 
különbséget tenni civil és katonai technológiák között. Ugyanazok az informatikai eszközök, közösségi és egyéb média felületek használhatók katonai célok elérésére, mint amelyeket a civilek is használnak nap, mint nap.

\section{FELHASZNÁLT IRODALOM}

[1] LAZAREDES N.: Ukraine's DIY drone war: Self-taught soldiers facing up to Russianbacked war machine, https://www.abc.net.au/news/2015-04-22/ukraines-diy-dronewar/6401688 (Letöltve: 2019. 02. 21.)

[2] TUCKER P.: How US technology could help ukraine without arming it, https://www.defenseone.com/technology/2015/02/how-us-technology-could-helpukraine-without-arming-it/104931/ (Letöltve: 2019. 02. 27)

[3] DAALDER I. [et al.]: Preserving Ukraine's Independence, Resisting Russian Aggression: What the United States and NATO Must Do, Atlantic Council of the United States 2015. ISBN: 978-1-61977-471-1 https://www.brookings.edu/wpcontent/uploads/2016/06/UkraineReport_February2015_FINAL.pdf (Letöltve: 2019. 02. 25.)

[4] MACHACYNSKI B.: Analysis in Ukrain: tomorrow's drone war is alive today, http://www.grouph3canada.com/index.php/intelligence/entry/analysis-in-ukrainetomorrow-s-drone-war-is-alive-today (Letöltve: 2019. 02. 18.)

[5] ROGIN J.: US hasn't kept ukraine aid promises, https://www.bloomberg.com/opinion/articles/2015-02-05/u-s-hasn-t-kept-ukraine-aidpromises (Letöltve: 2019. 02. 26)

[6] TUCKER P.:In Ukrain, tomorrow's drone war is alive today, https://www.defenseone.com/technology/2015/03/ukraine-tomorrows-drone-war-alivetoday/107085/ (Letöltve: 2019. 02. 18.)

[7] NAGY M.: Hogyan gyüjtsünk pénzt szabályosan, https://piacesprofit.hu/kkv_cegblog/hogyan-gyujtsunk-penzt-szabalyosan/ (Letöltve: 2019. 03. 10.)

[8] sz.n.: Aerorozvidka Facebook profil, https://www.facebook.com/pg/aerorozvidka/photos/?tab=album\&album_id=556901224 433363 (Letöltve: 2019. 02. 15.)

[9] Startup, https://hu.wikipedia.org/wiki/Startup (Letöltve: 2019. 04. 23.)

[10] sz.n.: Pixhawk wiring quick start, https://docs.px4.io/en/assembly/quick_start_pixhawk.html (Letöltve: 2019. 02. 12.)

[11] sz.n.: Naza MV2, https://www.dji.com/hu/naza-m-v2 (Letöltve: 2019. 02. 12.)

[12] EMELKO Y.: Ukrain's Crowdfunded Military drone, 2015 https://www.youtube.com/watch? $=$ =CK4myw8PQKk (Letöltve: 2019. 03. 2.)

[13] Sz.n.: Aerorozvidka honlap, http://bpla.in.ua/en/ (Letöltve: 2019. 02. 10.)

[14] sz. n.: New russian electronic warfare system identified in donbas, https://www.ukrinform.net/rubric-defense/2535420-new-russian-electronic-warfaresystems-identified-in-donbas.html (Letöltve 2019. 03. 02.) 
[15] WÜHRL T.: GPS navigációs problémák UAV alkalmazásokban, Hadmérnök, Robothadviselés 6. tudományos szakmai konferencia különszám, 2006. url.:

http://hadmernok.hu/kulonszamok/robothadviseles6/wuhrl_rw6.html (Letöltve: 2019. 02. 15.) 